HStud 27 (2013)1, 167-187

DOI: 10.1556/HStud.27.2013.1.11

\title{
ELECTIVE AFFINITIES: FERENC BÉKÁSSY, JOHN MAYNARD KEYNES, AND VIRGINIA WOOLF
}

\author{
ADRIANA VARGA \\ Indiana University \\ Bloomington, IN, USA \\ E-mail: avarga@umail.iu.edu
}

The extremely successful Cambridge Apostle Ferenc Békássy stunned his British friends and colleagues when he returned to Hungary at the beginning of World War I to fight on the side of the Central Powers. This article is an attempt to reconsider Békássy's reasons in light of historical and political events as well as in light of his poetic works. In particular, his long, dramatic poem "Adriatica", which is also the title of a volume published in 1925 by Hogarth Press, reveals the importance Békássy placed upon the Adriatic region not simply for its geographic beauty but, more importantly, for its cultural and historical significance as a bridge between modernity and classical times, between East and West, North and South.

Keywords: poetry, drama, translation, bilingualism, neoclassicism, modernism

$[\ldots]$

He fell without a murmur in the noise of battle; found rest

'Midst the roar of hooves on the grass, a bullet struck through his breast.

Perhaps he drowsily lay; for him alone it was still,

And the blood ran out of his body, it had taken so little to kill.

So many thousand lay round him, it would need a poet, maybe,

Or a woman, or one of his kindred, to remember that none were as he;

It would need the mother he followed, or the girl he went beside

When he walked the paths of summer in the flush of his gladness and pride,

To know that he was not a unit, a pawn whose place can be filled; 
Not blood, but the beautiful years of his coming life have been spilled,

The days that should have followed, a house and a home, maybe,

For a thousand may love and marry and nest, but so shall not he. [...]

These lines form the second, third, and fourth stanzas of a poem entitled "1914", written by the Hungarian poet Ferenc Békássy (7 April 1893 - 25 June 1915). The poem is included in the Cambridge Poets of the Great War, an anthology edited by Michael Copp and published in 2001. Although the editor explains in his introduction that it was an anthology of Cambridge poets published in 1921 (Edward Davidson, ed., Cambridge Poets 1914-1920. An Anthology. Cambridge: Heffer \& Sons Ltd., 1921) that inspired him to compile his own volume, the poem cited above was not included in the 1921 anthology but comes, rather, from a 1925 volume, Adriatica and Other Poems, published by Virginia and Leonard Woolf's Hogarth Press. Furthermore, in the 2001 anthology, Békássy's poem is included in a section entitled "The Enemy", which is described by the editor as containing poems that "reveal a generally sympathetic attitude towards Germany and towards German soldiers in particular. Among the trench poets a feeling of shared mutual suffering was commoner than one of hatred and revenge" (41). Békássy's poem, however, does not refer to Germany or to any country or nation in particular. The lack of reference is precisely what makes the poem effective because it allows for multiple readings/interpretations from readers with very different sets of expectations. Although the editor interprets the landscape described as referring "of course, not to an English one but somewhere on the Austro-Hungarian plains: "When the cow-herds answer each other and their horns sound loud and clear"" (42), the poem intentionally refers to a general pastoral scene rather than a specific geographical location. Placing this poem, then, in a section entitled "The Enemy" is not a reference to the poet's enemy - as with the other poems included in this section, whose authors are British - but to the fact that, at the beginning of World War I, Békássy left England for Austria-Hungary, enlisted as a Hussar and died in battle fighting against the Russians on the Eastern front, in Bukovina, near Csernovic/Cernauti (the birth place of Paul Celan). Sadly, the reference is clear: the "enemy" here is considered to be the poet himself.

While not unique, ${ }^{1}$ such an interpretation is highly misleading. Historical events show the circumstances of Békássy's departure to be much more difficult and complex. First of all, Békássy was not the only Apostle to enlist in the Austro-Hungarian army and fight against the Allies: Ludwig Wittgenstein volunteered, and, unlike the Hungarian poet, he not only survived the war but was decorated several times for his heroism in fighting against the British troops, on the Russian front, and on the Italian front. Furthermore, Paul Levy explains that: 
The Apostles were badly divided over the war, with some of the older men like Jackson, Ward, McTaggart and Whitehead being ferociously in favour of killing Germans, and the youngest, Bliss and Lucas, enlisting as their immediate predecessors, Békássy and Wittgenstein did on the other side. The intermediate generations of Apostles, the Strachey brothers, Keynes, Sydney-Turner, Woolf, Norton and Shove, were, with the exception of Rupert Brooke, vehemently opposed to the war. Dickinson, Sanger and Russell too were anti-war. Pro-Germanism, especially when it took the mild form of admiration for German Culture, was widespread among the war's opponents (277).

Békássy's choice is therefore worth reconsidering in this context. The Hungarian poet was thoroughly educated and deeply rooted in British linguistic, literary and cultural tradition and must have been torn between returning home and fighting for his country, and remaining in England. He is, thus, one of the forgotten - or perhaps intentionally left out - war poets.

Békássy's parents - a family of old Hungarian nobility - espoused liberal views, chose to first school their six children at home, and then send them all to be educated in England at the progressive Bedales School. It is here that Ferenc, their eldest, met for the first time and fell in love with Noel Olivier. In 1911 he began to read history at King's College, Cambridge, and the following year he joined the Cambridge Conversazione Society, also known as The Apostles, introduced by James Strachey and John Maynard Keynes - a secretive organization, a spiritual and intellectual elite with a membership limited to twelve, in its beginnings "Tory in politics, Evangelical in religion" (Allen i), which was also "a training-ground for a long succession of gifted and unusual men. It is also known to have played an important part in several literary and intellectual movements, the most famous of which is the Bloomsbury Group" (Allen vii).

In 1912 Békássy received a prize at King's College for his essay on Robert Browning. Friendships began to deepen: John Maynard Keynes invited him to visit Everleigh, Wiltshire. There were discussions and exchanges about literature, art, and politics with Virginia and Leonard Woolf, Duncan Grant, Noel Olivier and Rupert Brooke, among others. A letter from Rupert Brooke to Lytton Strachey also mentions Békássy as one of the guests at "a reading-party in dear old Lulworth" at the beginning of January 1912. The guest list included Maynard Keynes, Duncan Grant, and later, Harry Norton, Ka Cox, and Virginia Woolf (Hale 202-3). ${ }^{2}$ In return, Békássy invited Keynes to visit the Békássy family seat in Zsennye, Western Hungary. It is immediately after this visit in September 1912 that Keynes began to work seriously on his book, Indian Currency and Finance, which he published in 1913 (Moggridge 223).

Békássy was also partly responsible for the difficulties Ludwig Wittgenstein encountered when he tried to become one of the Cambridge Apostles. Brian 
McGuinness, Wittgenstein's biographer, writes that, although promoted to the Apostles, Wittgenstein was himself reluctant to attend meetings because of

Békássy, an Hungarian grandee who lived in splendour near Budapest, had been educated at a progressive school in England. (He was killed in Bukovina in 1915 and Keynes saw to the posthumous publications of his poems.) Inherited prejudice may have stood between him and Wittgenstein [...]. He later told Hungarian friends that he had voted against, and even had excluded, Wittgenstein. So on 8 December Moore wrote to Strachey to say that Wittgenstein had resigned (McGuinness 151).

McGuinness further explains that Strachey intervened and a compromise was reached: Wittgenstein's resignation was not recorded and he was not expected to attend meetings or read papers, "but he continued to take an interest in their affairs - discussing them with Moore (Moore's diary of 19.3.13) and asking in a letter from Norway whether a candidate of Hardy's had been elected. As a final token of his continued membership, he underwent the formality of 'taking wings' when he returned to Cambridge in January 1929" (152). Matters, however, were more complex. John Maynard Keynes' biographer, Robert Skidelsky, explains that Keynes, who was introduced to Wittgenstein by Bertrand Russell, engineered his Apostle membership even though Russell had warned him "that Wittgenstein would not thank him for it" (266). According to Skidelsky, Wittgenstein resented having to join a society that had Békássy as a member, being "appalled at the thought of having to spend his evenings in the company of Békássy - whom he detested as a Hungarian aristocrat - and a King's freshman called Francis Bliss, who did not number philosophical acumen among his accomplishments" (Skidelsky 266). Paul Levy, in turn, points out that Bertrand Russell himself was opposed to Wittgenstein's joining the Apostles (Wittgenstein joined on November $16^{\text {th }}$, 1912). The philosopher believed that the Society would be a waste of time for the young Austrian mathematician. His attitude "was widely interpreted as jealousy, and a desire to keep Wittgenstein to himself" (Levy 266). Whatever the reasons, it is clear that Békássy had come to be regarded very early in his studies as one of the brightest and most promising young minds at Cambridge. His membership in the secret Conversazione Society, which was for life, had its specific language and rituals, and took place by election only (interestingly, Thoby Stephen, Virginia Woolf's brother, and Clive Bell, Vanessa Stephen's future husband, were never elected), was a clear sign of this.

Békássy continued to write poetry in English and Hungarian and critical studies on British authors like Samuel Butler and Jane Austen as well as on the most important Hungarian poets of his own time - Dezső Kosztolányi, Mihály Babits, and Endre Ady - whose poems he also translated into English. In April 1914 he 
was one of the guests invited by Keynes to Virginia Woolf's Asheham House, Sussex $^{3}$ (Woolf Letters II 47). It is here that he presented his "Sonnet", which was also later included in Adriatica and Other Poems. ${ }^{4}$ Why, then, did he choose to return to Hungary and join the war effort on the side opposing his British friends, all the while with a sense of impending death clearly expressed in poems such as "1914"? This must have been an impossible conflict for the poet. He wrote, in one of his aphorisms, "Deep is delight; deep is feeling; but deepest of all is the eternal contradiction, the eternal paradox. There is insufferable contradiction in all things; and man's work and advancement have been devices to evade it. They have always ended by demonstrating it" (52). It is difficult to determine precisely the causes of the "insufferable contradiction" Békássy had to face: historical and political as well as literary and cultural factors must be taken into consideration.

After the 1848-49 Revolutionary War of Independence, Hungary's reputation was high in Great Britain, buttressed by the presence of the revolutionary leaders who took temporary or permanent refuge in England. An article published in The Times, November 1895, characterized Hungary as a "model constitutional State", "led by a group of exceptionally able statesmen, all of them of the moderate liberal type" (Jeszenszky 147). British politicians perceived Hungary as "the most stable element where all is instability" (The Edinburgh Review, vol. 188, no. 385 (July 1898), 31 as cited by Jeszenszky 147) - in a Central Europe where the balance of power could be easily disturbed by Germany, Russia, and the ethnic groups contained, for the time being, within the Austro-Hungarian Monarchy. However, by 1910 - when "human character changed" (Virginia Woolf, "Character in Fiction", 1924, Essays III, 421) - the traditional British perception of Hungary, of its role within the Austro-Hungarian Monarchy and within Central Europe, also began to change. There were several reasons. British journalists and historians like R. W. Seton-Watson and Wickham Steed began publishing critical reports about the conditions of the national minorities within the Monarchy. The international political situation had also changed: Russia came to be perceived as an ally that would help set the balance against the growing German hegemony in Europe and in the world. British politicians found it useful to encourage Pan-Slav aspirations in Central Europe and began to question Hungary's important role within the Dual Monarchy. There was yet a third factor for Hungary's loss of prestige in Britain and the changes in British foreign policy toward it: early $20^{\text {th }}$-century Western European democratic developments "were not followed in Central and Eastern Europe, and that made Hungary appear more backward and more conservative than she really was" (Jeszenszky 155).

The question remains, then, why such a liberal-minded, multilingual, Western-educated anti-war poet chose to return to Hungary at the beginning of World War I, enlist in the Austro-Hungarian army, and give his life fighting on the Eastern front. It is difficult to understand Békássy's choice especially since archives 
that contain many of his unpublished letters and poems remain unavailable to the public. Even so, the answer may not be entirely impossible to discern. Békássy must have been acutely aware of the criticism brought by Seton-Watson against his country, criticism brought even closer to Cambridge and the Apostles through the work of Harold Nicholson, Leonard Woolf, and even John Maynard Keynes. He must have had arguments with his friends and must have sensed a complete lack of understanding as far as his situation was concerned. To give just one example, David Garnett relates a conversation with Keynes about the poet's departure:

\begin{abstract}
Maynard told me that he had succeeded in raising enough money for Ferenc Bekassy to leave England the night before [August $10^{\text {th }}$, 1914]. The banks were shut owing to the moratorium and Bekassy was anxious to return to Hungary to fight against Russia. War had not been declared between Britain and Austria-Hungary until the morning after Bekassy left.

I said I thought that Maynard should have refused to find the money on the double grounds that he was sending a friend to his death and strengthening the enemy forces.

Maynard disagreed violently. He said he had used every argument to persuade Bekassy not to go - but having failed to persuade him, it was not the part of a friend to impose his views by force, or by refusing to help. He respected Bekassy's freedom to choose, though he regretted his choice. My second argument was ridiculous: what was one man in a score of millions? I agreed that friendship was more than patriotism, but asked him if he would restrain the friend who contemplated suicide, or would he lend him money to buy poison? Maynard replied that in certain circumstances he would lend him the money - if it was a free choice, made by a sane man after due reflection, for compelling causes (Moggridge 240).
\end{abstract}

D. E. Moggridge, one of Maynard Keynes' biographers, questions the way in which David Garnet recounted these events, pointing out that Britain declared war on Austria on 10 August, and, since Békássy left England the previous Sunday, August 9, "there should have been no problem in getting cash" for him (240). Furthermore, Keynes kept detailed records of his expenses that included notes of loans and small gifts, yet he did not record any loan to Békássy for what must have been a very expensive journey at the end of that summer (240).

Robert Skidelsky, on the other hand, picks up on David Garnett's letter and puts in a different light in an earlier biography on Maynard Keynes, arguing that Békássy was "far from being standard Apostolic Man, preferring Nietzsche to Moore, and action to contemplation, though he too had poetic leanings" (Skidelsky I 265). In volume two of the same biography he takes these arguments even further. Using Clive Bell's study, Civilisation (1928), despite the fact that 
Bell's arguments are of a very different nature and do not take the same direction as Skidelsky's - the biographer maintains that

Bloomsbury could not be heroic in the way in which Rupert Brooke or Békássy or later Julian Bell were heroic, that is happiest under fire. But it could happily contemplate the spectacle of heroism in Michelangelo, Coriolanus or in the character of Perceval which Virginia Woolf created in her novel The Waves - perhaps an evocation of her brother Thoby, the 'Goth' who had died of typhoid in 1906 (Sidelsky II 16).

To judge Békássy's choice as the deed of a heroic character "happiest under fire" is a complete misunderstanding of the Hungarian poet's personality, intellectual activity, and actions. Not only some of the war poems written just before his death in 1915, but also his earlier, longer dramatic poem, Adriatica, show that, on the contrary, Békássy shared and expressed in his writings the philosophic and aesthetic views G. E. Moore had discussed in his Principia Ethica (1903): while good is indefinable, the greatest goods are personal affection and aesthetic enjoyment.

Keynes' own letter to his lover and best friend, Duncan Grant, reflects a similar lack of understanding:

\footnotetext{
I have heard from Noel [Olivier] that she has just got a letter from him [Bekassy] written five days before starting for the front. It seems now an extraordinarily short time ago that he came rushing back for his sister, and how walking through Leicester Square after going to the Picture Palace near there on the night when war was certain, I very depressed but he excited and not very depressed, he said, - 'It will be a very wonderful experience for those of us who live through it.' He was certain to be killed. When one thinks of him, it is his goodness, I think, one seems to remember. But it is no use talking about him I think it's better to forget these things as quickly as one possibly can (Moggridge 241).
}

A reader familiar with Békássy's anti-war sentiments expressed so strongly in both his Hungarian and English poetry might doubt the recollection that he referred to war as a wonderful experience. Furthermore, with respect to Keynes' last sentence, the act of remembrance Virginia and Leonard Woolf made by publishing Békássy's poems in 1925 becomes even more significant. It shows the Woolfs' willingness to enter and explore those spaces between cultures and languages, even as Virginia understood and affirmed in several of her essays that complete and accurate understanding is impossible. The novelist was aware of the historical, political, and cultural dimensions of this problem, and discussed them in her fiction and criticism. In Mrs. Dalloway, for example, Clarissa's complacent ignorance of the differences between Armenia and Albania surfaces in her 
thoughts as she drifts into her afternoon nap: "no, she could feel nothing for the Albanians, or was it the Armenians? But she loved her roses (didn't that help the Armenians?) - the only flowers she could bear to see cut" (157). Trudi Tate aptly explains this confusion as Woolf"s merciless satire of the British upper class "who managed the social and economic aspects of [World War I] and treated the survivors so badly afterwards" (Tate 153).

Furthermore, because of her work of translation from Russian and Greek, Woolf understood both the possibility and impossibility of exploring cultural and linguistic spaces that are not one's own. Along these lines, Maria DiBattista has pointed out that what we might call

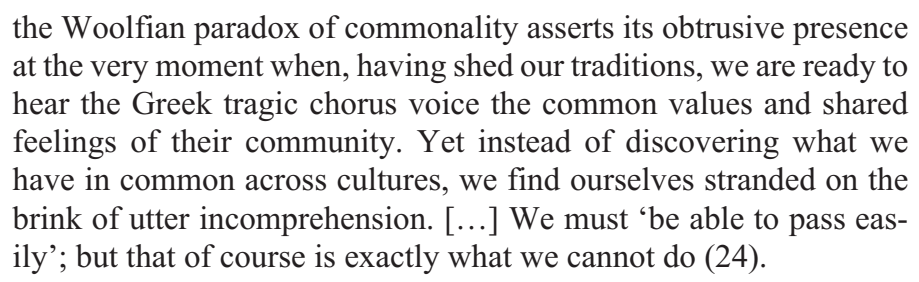

I would like to argue that, despite these differences, it is language itself, particularly poetic language, that opens a window toward an "other" cultural and linguistic world. Drawing a parallel between Ferenc Békássy and Virginia Woolf as writers in the spirit of an elective affinity may help elucidate this point. While Woolf did not write anti-war poetry, novels such as Jacob's Room, Mrs Dalloway, To the Lighthouse, and Between The Acts may be considered large-scale, anti-war, elegiac prose poems. The first two reflect on the destruction of an individual life, while the latter (particularly Woolf's last novel) are meditations on the destruction threatening an entire community as it reenacts its history (through the custom of a pageant in Between the Acts) even in the face of war. The bonds that tie the members of this English community closely together are those of a language that, as Lucy Swithin observes, is not created but creates and defines its speakers:

'The nursery,' said Mrs. Swithin. Words raised themselves and became symbolical. 'The cradle of our race",' she seemed to say (Between the Acts, 71, my italics).

Although Békássy was, unlike Woolf, a bilingual author entirely at home in English - as his poetry and critical studies attest - he felt the same kind of closeness to his native language and culture as Woolf felt to hers. By comparing poems he wrote in English and Hungarian, it is possible to notice that Békássy drew on very different traditions in the two languages - in English, on British literary traditions, in Hungarian, respectively, on Hungarian. Yet it is also possible to notice that the language of his Hungarian poems is of a very different nature, if not more com- 
plex and suggestive. A comparison of two of Békássy's poems exemplifies this. Their subject is similar enough that they seem almost translations of each otheralthough, clearly, they are not.

Written in English, "The Last Fragment" can be dated with approximation to 1913 or 1914. It describes a desert-like country in which men wander forsaken:

\author{
On such a night it seems \\ As though the country were a desert; men, \\ If any walk here, spirit-like; and dreams \\ Grow few, and spoken words uncanny then. \\ Forsaken roads there lie across the sand, \\ Pools curl beneath some over-knotty tree, \\ And curly clouds pass far above the land. \\ $[\ldots]$ \\ I suffered there; so that I used to brood \\ Seeing with incomprehension something strange, \\ Till time and good remembrance worked a change. [...]
}

"A sivatagban" (In the Desert), a poem Békássy wrote in Hungarian, January 1915, also describes a desert, but in very different style and language than "The Last Fragment". Even in a very literal translation of "A sivatagban", in which I have abandoned the rhythm and alternating end rhyme of the Hungarian original, it is possible to see how much more richly ambiguous language is than in its English counterpart. Language does not send to a world outside of itself but seems to be a self-enclosed and self-reflexive world or system. Consider, for instance, the lines:

\footnotetext{
Already nowhere is the city's colorful dream In which every lamplight: fiend; Sound disappears here in the wild, There so much proud ore rings in the street There the spirit startles, and the jumbled noise Not stunned, flies through the sky; Here: you must fear; on the desert's borderlands Devastating death walks about at will. ${ }^{6}$
}

The difference between the two poems should not surprise: "What is sometimes called Modernism was associated more than many earlier movements with multilingual aspirations. [...] The poems composed in French by Rilke, T. S. Eliot, and Ashbery are inferior to their verse in German and English [...]" (Szegedy-Maszák 155). Perhaps, then, the difference is the relationship a poet - the native speaker has with his or her own language, a relationship that may be virtually impossible to duplicate in a second language or through translation. Words are not something 
to be commanded, Irma Rantavaara remarked in her analysis of The Waves, but "something fragile, light, elusive, likened to butterflies, balloons, bubbles":

the art of writing means having at one's beck and call every word in the language, of knowing their weights, colours, sounds, associations, and thus making them, as is so necessary in English, suggest more than they can state (Rantavaara 39).

It is in light of this that we may be able to understand the question Virginia Woolf raised in "The Russian Point of View" - an essay published the same year as Békássy's volume of poetry: can individuals belonging to different cultural and linguistic communities understand each other's "sense of common values which make for intimacy, and sanity, and the quick give and take of familiar intercourse" (182)? It is in light of this that Békássy's need to return to his country - to which he seems to hint even in "The Last Fragment", in the lines cited above - at the outbreak of World War I must be considered and understood.

1925 was also the year The Hogarth Press published John Maynard Keynes' A Short view of Russia. Its publication the same year as Békássy's volume of poems may not have been coincidental. Were the conversations Keynes recalled having with Békássy before his departure for the front more meaningful than the letters and diaries record? Were Békássy's reasons for returning to Hungary and fighting on the side of the Central Powers so complicated that even great minds such as Keynes' could not understand them at the time? Keynes, the author of The Economic Consequences of the Peace (1919), felt he had to reconsider them at the end of the war. In August 1925, Keynes married Lydia Lopokova, the famous Ballets Russes dancer, and the couple travelled to Russia to meet the bride's parents. The thoughts Keynes expressed in the short book promptly published by Hogarth Press, if vitriolic at times, ${ }^{7}$ were influenced by freshly acquired impressions. Although sympathizing "with those who seek for something good in Soviet Russia", Keynes explained his belief that the system he had just seen with his own eye was deeply destructive at all levels:

Comfort and habits let us be ready to forgo, but I am not ready for a creed which does not care how much it destroys the liberty and security of daily life, which uses deliberately the weapons of persecution, destruction, and international strife. How can I admire a policy which finds a characteristic expression in spending millions to suborn spies in every family and group at home, and to stir up trouble abroad? [...] How can I accept a doctrine which sets up as its bible, above and beyond criticism an obsolete economic textbook which I know to be not only scientifically erroneous but without interest or application for the modern world? [...] It is hard for an educated, decent, intelligent son of Western Europe to find his ideals here, unless he has first suf- 
fered some strange and horrid process on conversion which has changed all his values (13-14).

As a highly educated and westernized man but, at the same time, an "intelligent son" of East-Central Europe, Békássy may have been aware of the turn events would take well before his British friends. Aware of the historical past of the region (the 1848 War of Independence, to give just one example), he must have understood the severity of the Russian threat in 1914, before it became the threat of Soviet Russia, which so troubled Keynes in 1925. Russia's aspirations "to fill the vacuum left by the withdrawal of Turkey from the Lower Danube area" (Romsics 2) were no secret at the time. Historians have pointed out that:

The aspirations of the Romanov Monarchy in the Balkans reached back to the time of Catherine the Great. These plans had undergone a metamorphosis by the beginning of the $20^{\text {th }}$ century, but their main thrust remained the same: to control the Dardanelles and their hinterlands. A part of the evolving project affected the Austro-Hungarian Empire both directly and indirectly. [...] the dismemberment of Hungary and of the whole Austro-Hungarian Monarchy was among the war aims of Russia from the start of the war (Romsics 2).

It must have been disturbing for the young Apostle to realize that none of his highly-educated Cambridge colleagues understood this perspective, and threatening to realize that the public opinion of the adopted culture he loved and admired had turned against his own.

How Békássy thought of the region he came from and wanted to fight for is expressed nowhere more clearly than in the poem that lends its title to the volume published by Virginia and Leonard Woolf in 1925. "Adriatica" was clearly a topic of discussion among the Cambridge friends who had survived the war:

Lucas was wounded and served out the war in an intelligence unit. Békássy and Bliss were killed in action, and Brooke died of an infection on Skyros. Then the Apostles began to count the cost. Norton told Moore of Békássy's death at High Table at Trinity. Gordon Hannington Luce, who had carried on an extensive correspondence with him and had collected various versions of his Adriatica, wanted to know all the details of Békássy's death. Luce wrote and then destroyed, a series of poems raging at his and the Apostles' loss (Lubenow 195).

The critic and poet Frank Laurence (Peter) Lucas, (who had several of his own works published by the Hogarth Press, and who wrote the Introduction to Békássy's book), and Gordon Hannington Luce (an Apostle friend of Keynes, who also published of edition of Poems with Hogarth Press, with decorations by 
Duncan Grant (Woolf Letters II n1 596)) both very likely supported the publication of Békássy's poems.

In "Adriatica" Békássy explores some of the aesthetic tenets of Neoclassicism several years before T. S. Eliot discussed them in essays such as "Tradition and the Individual Talent" (1917), "The Metaphysical Poets" (1921), or "Four Elizabethan Dramatists" (1924). It describes a voyage at sea in the epic tradition of the Odyssey, yet refuses to invoke the "glamour" of "goddesses or heroes": "But though no glamour there / Of goddesses or heroes well could be, / Yet most distinguished our ship's company" (15). The poem is infused with the elements of the pastoral and the romance, yet its quest is not the same as that of courtly love, while giving the impression that it may be. For instance, Chapter I of "Adriatica" begins with the view of a pastoral scene as the travelers sail through the gulf of Quarnero, passing by Fiume, Trieste, and Lussin:

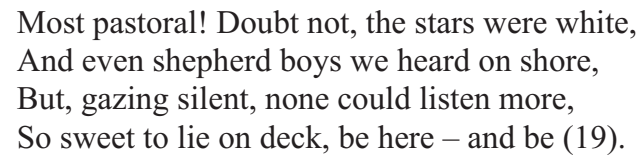

With its Introduction, eight chapters, and epilogue, the poem is dedicated to a reader who knows or desires to know the world it depicts:

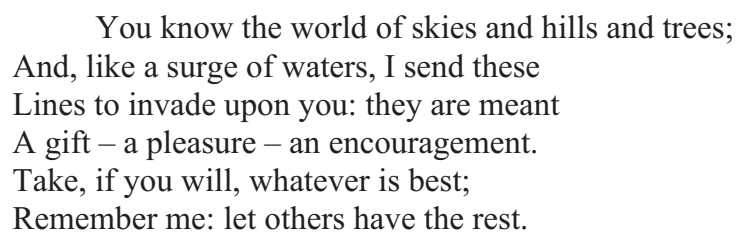

It may also be interpreted as a meditation on the nature of love, religion, and the nature of being in the tradition practiced by the metaphysical poets. Indeed, one of the travelers aboard the ship that is the poem itself, is Herbert, a possible reference to either George Herbert (1593-1633), the Welsh-born English poet who attended Trinity College, Cambridge, and excelled, among other things, in languages and music; or, perhaps, to his elder brother, Edward Herbert of Cherbury (1583-1648), a graduate of Oxford, an equally talented metaphysical poet and a diplomat, whose philosophical concerns bring him close to the seventeenth-century Cambridge Platonists: Herbert of Cherbury is the author of De Veritate (1624), the first English metaphysical treaty, and of De religione gentilium (1663) from which, in large part, derived his reputation as the father of deism.

The neoclassical nature of Békássy's poem - which brings together such different styles with no claim to "making it new", yet is highly original precisely because of the infusion of Modernism with a wealth of allusions to past literary 
movements and genres - is made clear at the very beginning of the Introduction: "It is no stately ship, sere-sailed, serene, / But one that's been where many else have been; / Graced with no compliment of classic sea - Pago, Permuda, Zurt, its Cyclades" (15).

Five characters begin a sea voyage from San Pietro to Venice, and along the Dalmatian coast (from Zara, ${ }^{8}$ to Comisa (Komiza), Lissa, ${ }^{9}$ Curzola,${ }^{10}$ Ragusa, the Acroceraunians) to Corfu. The travelers, who are also dramatis personae, "Persons of the Play" (24) in a verse drama are: Amrita - "who had brought us here, awhile / With pleasant conversation to beguile / The uneventful days" (19), and who, we are told at the end of the poem, had planned not only the journey itself but also, along the journey "to weed / Out everything too vehement, / Not for the Adriatic meant" (49). - Antony, Herbert, Philemon, with the Narrator at the helm. Their purpose, to engage in "discourse, made fleet and slight with wit":

Jocund, awake, we laughed to our content, Nor heeded much the night, until there went A shiver through the cordage; soft, a word Fell, loitering: deep waters suddenly stirred In our discourse, made fleet and slight with wit, Of this our journey and the end of it (20).

Restless, Antony - who differs from the other characters in that he seeks action ${ }^{11}$ begs for a kind of song a gondolier might provide in Venice. Instead, the travelers are engulfed in silence and feel they have left their former lives behind:

For suddenly our former life was sundered

Quite from us by the quiet sky and sea.

There seemed no man upon the earth but we.

Once let the coffin-boards of cabins hoard

The treasure that is man, a new accord

Strikes out all life unharmonised (22).

In the second chapter, the Narrator is witness to Philemon and Antony's coming together and drifting apart. Aware of Philemon's pain, the Narrator concludes:

- What could I know of any hopes and fears And pain of him? Yet now I know, since then, That every word was pain. The loves of men, I know not by what logic, have not had Their due happiness [...] (25).

Chapter three follows the same pattern, with Herbert and Amrita this time. Before the lovers' fated separation, the travelers disembark on Lissa - a scene that might remind readers of the famous Watteau painting, "L'Embarquement pour Cythere" 
(1717, Louvre) or of "Pilgrimage to Cythera" (1718-21, Charlottenburg Palace, Berlin), were it not that Békássy's description is not of a landscape in Rococo style, but of an arid, desert-like island surrounded by a sea of marvels:

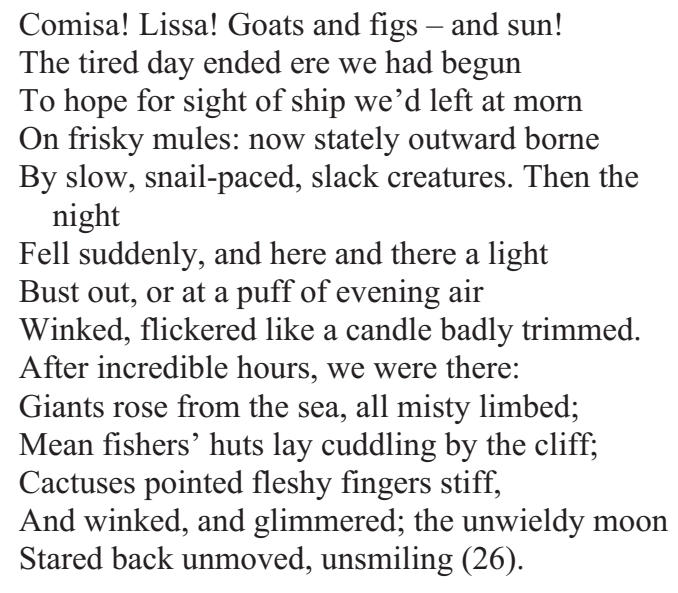

Even so, Békássy's poem, like Watteau's painting(s), depicts several couples adopting roles and postures that are ambiguous - difficult to interpret or define. Back on deck, at night, crew asleep, the poet-narrator overhears a conversation between the two lovers, Herbert and Amrita, of which he reproduces snippets, not in the iambic pentameter of his previous "verse drama" but by using, in contrast, catalectic trochaic tetrameter, which Shakespeare was so fond of using for the speech of his fairies:

At first, so low they spoke, but here and there a word. ...

$[\ldots]$

How could lovers live more wisely

Than the way that lovers use?

Sport she early, late arise he,

Peace and ardour neither lose.

But though Romeo is happy

In his mistress' sheets and arms,

Wind's his wisdom if mayhap he

Find she doth refuse her charms.

Solitary love! Ah! Senseless

Lovers grow, denied their lust,

Foolish in their pained intenseness

When they sigh because they must [...] (27). 
Another connection with Watteau may be drawn via Paul Verlaine's "Clair de lune" (Fêtes galantes, 1869), in which personal sentiments are masked by pastoral evocations of $18^{\text {th }}$-century paintings and by scenes from the Italian Commedia dell'Arte:

Tout en chantant sur le mode mineur

L'amour vainqueur et la vie opportune,

Ils n'ont pas l'air de croire à leur bonheur

Et leur chanson se mêle au clair de lune, $[\ldots]$

In "Adriatica", as in Verlaine's Fêtes galantes, conversations and scenes appear to be elegant, even frivolous. Yet one senses, behind the mask of characters who bear names alluding to Classical and Renaissance literature, the depth of longing and despair, passions that are "guised in craft with due constraint" (29):

So nigh
Lay thought to desperation in the mind
Of Herbert, as of one who cannot find
A sheltered place; whose endless road must wind
On endless desert. Of his love he spoke:
His mind, in misery beneath the yoke
Unbreakable by thought, which thought must bear;
His body, that for respite turned to her,
Where none he found; so driving, clay to clay,
Mind to decay and body to decay,
He had crossed every limitation, seen
All things, and all made foul; dried up and lean
The flesh of knowledge and the fat of love (36).

Most importantly, perhaps, the quest of Békássy's poem is not that of the courtly Romance. Romantic love is constantly frustrated. Herbert, for instance, rejected and deserted by Amrita, responds with a sonnet:

[... O do not seek to hoard for other years

What uncontrolled appears and disappears.

Refusing to remember, in that mood,

How happy lovers are, how love is good

That moulds to destinies the formless clay. [...] (30)

Herbert and the Narrator seem, paradoxically, to find value in the transience of love and, later in their voyage, they recognize the possibility of another kind of path toward a different kind of love:

There is a bloodless way of Calvary

Where love itself is pain to feel and see.

But pleasanter than pleasure's self was this 
And how could any shame at all be his Who to the fountain when dumb life began Came with the proud intelligence of man? (37)

Refusing Herbert's love, Amrita, on her part, prefers, in chapters four and five of the poem, to descend with Antony onto Curzola. From their conversation we learn that the voyage has been planned by Amrita ("Yet $I$ contrived to float this company!" (33)), who now asks Antony to return and comfort Herbert. In an unexpected turn at the end of the poem - after having stopped on Ragusa and Lacroma where Theodora, Amrita's guest, joins the travelling party - the Narrator and Amrita are left alone together on Corfu. On their way back home, the Narrator confesses his secret:

\footnotetext{
I, left alone

After Cattaro, wrote this; pondered much

On love's chief virtues, men, and other such

Themes poet-worthy; telling all I can

Of them, and how Amrita deals with them.

Amrita and myself, one couple more.

I have not done her justice; will not; nor

Has telling you of $u s$ been my intent:

She is my secret, I my own, my Friend!
}

Combining various poetic and narrative strategies, "Adriatica" is a verse drama that may also remind of the dramatic experiments, pageants undertaken by authors like E. M. Forster and Virginia Woolf in 1930s, the difference being that the 'pagina', the movable stage, has become a ship's deck. Most importantly, the setting for this drama is not the English countryside. Békássy takes his characters and readers outside of England into a region, a world he knows well, which is his own, if we may equate, in this instance, the author with the poet-helmsman:

\footnotetext{
- If I could talk to my own heart's content, I would tell over these, the things that meant Most to me on the journey: I would say Much of the winds and waters, day by day, Much of the islands, for I know them well; Of how I sailed, what I saw; but I must tell A story of much love and little gain, Much happiness, and wit, before again I turn to my affairs (39).
}

One can only speculate whether or not the poet speaks autobiographically of a journey that took place in reality with characters depicting Békássy's friends, a kind of poem à clé, or whether this is an imaginary journey - one on which Virginia Woolf's Orlando would also embark, on his way to Turkey, only three years 
after the publication of Adriatica and Other Poems - in which characters are aspects, or facets, or masques of the poet-narrator-helmsman. In either case, the Dalmatian coast - "No doubt with topics and discussions high / They paced the philosophic hills" (35) - and Adriatic Sea to which Békássy wanted to transport his friends and readers formed a bridge between modernity and classical times, as well as between East and West, North and South. The shepherds the poet depicts are Dalmatians whose song may be associated with the "singer of tales". Even though written in a language other than the poet's native language, "Adriatica" is a highly original masterpiece, a self-reflexive poem grown out of several British and European poetic styles and traditions, which refers, at the same time, to a world that was very much part of Békássy's own - the Austro-Hungarian Monarchy. This is a crucial aspect that must not be ignored when considering the poet's reasons for returning to Hungary and enlisting to fight in the war on the side of the Central Powers.

\section{Works Cited}

Allen, Peter. The Cambridge Apostles. The Early Years. Cambridge: Cambridge University Press, 1978.

Békássy, Ferenc. Adriatica and Other Poems. London: Hogarth Press, 1925.

Békássy, Ferenc. Békássy Ferenc. Egybegyüjtött írásai [Collected Writings of Ferenc Békássy]. Budapest: Aranymadár Alapítvány, 2010.

Copp, Michael. Cambridge Poets of the Great War. An Anthology. Madison: Fairleigh Dickinson University Press, 2001.

DiBattista, Maria. “An Improper Englishwoman: Woolf as a World Writer.” In Woolf Across Cultures, edited by Natalya Reinhold. New York: Pace University Press, 2004.

Gömöri, George. "Ferenc Békássy, Rupert Brooke, and Noel Olivier." The Hungarian Quarterly 51, 199 (2010): 105-13.

Hale, Keith. Friends and Apostles. The Correspondence of Rupert Brooke and James Strachey, 1905-1914. New Haven: Yale University Press, 1998.

Jeszenszky, Géza. Az Elveszett Presztízs [Lost Prestige]. Budapest: Magyar Szemle Könyvek, 1994.

Jeszenszky, Géza. "British Policy towards Central Europe during World War I." In $20^{\text {th }}$ Century Hungary and the Great Powers, edited by Ignác Romsics. New York: Columbia University Press, 1995.

Keynes, John Maynard. A Short View of Russia. London: The Hogarth Press, 1925.

Levy, Paul. G. E. Moore and the Cambridge Apostles. New York: Holt, Rinehart and Winston, 1979.

Lubenow, W. C. The Cambridge Apostles, 1820-1914. Liberalism, Imagination, and Friendship in British Intellectual and Professional Life. Cambridge: Cambridge University Press, 1998.

McGuinness, Brian. Wittgenstein: A Life. Young Ludwig 1889-1921. Berkeley: University of California Press, 1988.

Moggridge, Donald Edward. Maynard Keynes: An Economist's Biography. London: Routledge, 1992.

Rantavaara, Irma. Virginia Woolf's The Waves. Helsinki: Societas Scientiarum Fennica, 1960. 
Romsics, Ignac, ed. Twentieth-century Hungary and the Great Powers. New York: Columbia University Press, 1995.

Skidelsky, Robert. John Maynard Keynes. Vol. 1. Hopes Betrayed 1883-1920. New York: Viking Penguin Inc., 1986.

Skidelsky, Robert. John Maynard Keynes. Vol. 2. The Economist as Saviour. 1920-1937. New York: The Penguin Press, 1994.

Szegedy-Maszák, Mihály. Literary Canons National and International. Budapest: Akadémiai Kiadó, 2001.

Tate, Trudi. "Mrs Dalloway and the Armenian Question." In Trudy Tate, Modernism, History and the First World War. Manchester University Press, 1998.

Wilkinson, L. P. Kingsmen of a Century. 1873-1972. Cambridge: Cambridge University Press, 1981.

Woolf, Virginia. The Common Reader. First Series. London: Hogarth Press, 1925.

Woolf, Virginia. The Essays of Virginia Woolf. Vol. III 1919-1924. Edited by Andrew McNeillie. New York: Harcourt, 1988.

Woolf, Virginia. The Essays of Virginia Woolf. Vol. IV 1925-1928. Edited by Andrew McNeillie. New York: Harcourt, 1994.

Woolf, Virginia. The Question of Things Happening. The letters of Virginia Woolf 1912-1922. Vol. 2. Edited by Nigel Nicholson. London: Hogarth Press, 1976.

Woolf, Virginia. The Waves. San Diego: Harcourt Brace Jovanovich, 1978.

\section{Notes}

1 In Kingsmen of a Century 1873-1972, L. P. Wilkinson explains that Békássy "has a strange memorial in the College. After the War some Fellows could not bear the idea that the name of an enemy should be included in the list of the British dead inscribed in the wall of the War Memorial. The majority accepted a compromise, and his name may be found in isolation on the inner left wall of the entrance arch" (279). See also George Gömöri’s article, "Ferenc Békássy, Rupert Brooke, and Noel Olivier."

2 'RB, December ['Dec 19.1911' written in pencil at top, probably by Lytton] 24 Bilbon Road, Rugby to Lytton Strachey

"Dear Lytton.

There's going to be a reading-party in dear old Lulworth. In January: $3^{\text {rd }}$ or $4^{\text {th }}-$ Norton, I think, is going to be there. And Ka and I. And perhaps his Lordship. And possibly Virginia. Will you come? It will cost you 30/ - a week, perhaps. Everybody will be writing plays. I suppose it will be dreadfully Apostolic .. If you came earlier, you'd find a different lot - S[ignor]. [Ferenc] Békássy amongst them. But I recommend the later.

Could you come - a week - or if not, less, even?

Rupert"

[Editor's note]: Brooke had also invited Maynard Keynes for the earlier week and asked him to Bring Duncan Grant. This is why he suggested the later week to Strachey, for Strachey had not forgiven Keynes for taking Grant from him. (Hale 202-3)

3 In her letter to Molly MacCarthy Woolf wrote that she and Leonard Woolf would be away in Cornwall the week when the Apostles met at Asheham: "We've let it [the house] to Keynes for a reading party next week, and we go off to Cornwall, while they're here. Perhaps you will see them. I gather they are to be mostly Apostles" (Woolf Letters II 47). 
4 SONNET

I am that bondsman whom an earthly grace

Has to your whims unquestionably knit;

Love clamoured in my earliest embrace

That I should perfect and accomplish it.

Do not despise me: for the task is great;

I am not humbled in a lowly cause:

Love is no child, in ignorance elate,

Nor laughs and claps its hands without a cause.

Come therefore; if my love be like the sea

And cannot its own ecstasy contain,

Be you my gentle wind and let me be

Your origin and virtue once again;

And tears and kisses be the fountain whence

Shall flow a new world's perfect innocence.

Asheham House, April 24, 1914.

5 The poem below is reproduced as it appears in Adriatica and Other Poems (1925):

THE LAST FRAGMENT

Now deep midnight must cling to hills and spurs

In that far country where my friend and I

Once walked on earth together, and the firs

Will shake a little as the wind will die.

Each grain of sand must shift uneasily,

And hazy mists will come when no wind stirs

Over the heath. On such a night it seems

As though the country were a desert; men,

If any walk here, spirit-like; and dreams

Grow few, and spoken words uncanny then.

Forsaken roads there lie across the sand,

Pools curl beneath some over-knotty tree,

And curly clouds pass far above the land.

But that dim country woke no fantasy,

Conjured no judgment out of every mood.

I suffered there; so that I used to brood

Seeing with incomprehension something strange,

Till time and good remembrance worked a change.

The elements of Wonder lie beneath

The least or greatest object viewed but so.

Tall grasses socketed with haulm and sheath,

And bodies growing as the grasses grow;

Love that was love a thousand years ago....

A sivatagban

Rég elhagyott házak között az út

Túl a nagyváros rengeteg kövén

Széljárta homoksivatagba fut

Pár csenevész fa közt, melynek tövén 
Gaz gazzal küzdve mégis megterem Ott a homokban - és utat jelez,

De nincsen út a puszta földeken -

Korhadt kidőlt határfa görnyedez.

Nem élők birodalma! Fű se nől, Eltévedt éhes eb se kóborol:

S pár lépést jössz a házsorok felől,

Se ház, se város nincsen már sehol.

Nincs már sehol a város színes álma Amelyben minden lámpafény: lidérc; Belevész itt a hang a pusztaságba,

Ott cseng az utcán mennyi büszke érc.

Ott kedv riad, s az összevissza lárma

Meg nem döbbenve ott az égbe száll;

Itt: félni kell; a sivatag határba'

Kedvére jár a romboló halál.

Jaj annak aki erre tévedett!

Tủrhetetlen itten, átkozott a lét,

$\mathrm{S}$ aki a sivatag bolondja lett,

Kín s iszonyat elfogja életét.

Azt mondják itt egy ember jár, ki holt

$\mathrm{S}$ a messze földeken nyomot keres

$\mathrm{S}$ amerre régen vándorútja volt

Vár új halottat, s új halálra les.

...Kedvem, szerelmem, munkám, szenvedésem

Virágos kertjét el hogyan hagynám?

Hogy most keressem már halott reményem'

A CÉLTALANSÁG vad sivatagán!

(Békássy Ferenc egybegyüjtött írásai 51)

In The Desert

The road runs between long-abandoned houses

Beyond the city's many stones

To the wind-swept sands

Between a few sickly trees at whose base

Weed struggling with weed grows nevertheless

There in the sand - and points the road,

But on the wasteland there's no road -

Border trees stoop rotting.

It is not the empire of the living! Even the grass doesn't grow

Nor does the hungry lost dog stray 
And in a few steps you come from the rows of houses,

No house and no city anywhere anymore.

Already nowhere is the city's colorful dream

In which every lamplight: fiend;

Sound disappears here in the wild,

There so much proud ore rings in the street

There the spirit startles, and the jumbled noise

Not stunned, flies through the sky;

Here: you must fear; on the desert's borderlands

Devastating death walks about at will.

Oh, those who stray here!

Unbearable, here life is cursed

Agony and terror imprison the life

Of one who has become the desert's madman.

They say a dead man walks here

Seeking footprints in faraway lands

And where he had wondered long ago

He awaits new dead and seeks new death.

...How can I abandon the flower garden of

My spirits, my love, my work, my anguish?

To seek now with my already dead hope

In the wild desert of aimlessness.

7 "If we want to frighten ourselves in our capitalist easy-chairs, we can picture the Communists of Russia as though the early Christians led by Attila were using the equipment of the Holy Inquisition and the Jesuit missions to enforce the literal economics of the New Testament; but when we want to comfort ourselves in the same chairs, can we hopefully repeat that these economics are fortunately so contrary to human nature that they cannot finance either missionaries or armies and will surely end in defeat?" (12).

8 Zadar, called Zara when under the authority of the Republic of Venice in the $15^{\text {th }}$ century. This is also the name used when Zara was part of the Habsburg empire in the $19^{\text {th }}$ century.

9 The old Venetian name for the Adriatic island of Vis, where a battle took place in July, 1866, between the Habsburg Empire and Italy as part of the Third Italian Independence War. The Italian defeat at Vis was overshadowed by the Prussian victory over Austria at Königgrätz, which, in turn, led to the establishment of the Austro-Hungarian Monarchy in 1867.

10 Korcula, southern Dalmatia, an island that changed hands several times throughout history between Venice, the Kingdom of Hungary, the Austrian Empire, Austria-Hungary, Yugoslavia, and Croatia.

11 He could not rest in miserable ease,

But with impatient fingers longed to do

Some - any - thing he might be driven to.

Action clung round about him: pleasures brought

New Ferment for the nectar of his thought. (21) 
